\title{
Physical and Chemical Properties of the Rice Straw Activated Carbon Produced from Carbonization and $\mathrm{KOH}$ Activation Processes \\ (Sifat Fizikal dan Kimia Karbon Teraktif Jerami Padi yang Terhasil melalui Proses Pengkarbonan dan Pengaktifan $\mathrm{KOH}$ )
}

\author{
Mohamad Jani SaAd, Chin Hua Chia*, SARani ZaKaria, Mohd Shaiful Sajab, Sufian Misran, Mohammad \\ HARIZ ABDUL RAHMAN \& SIEW XIAN CHIN
}

\begin{abstract}
In this study, highly porous activated carbon was produced from rice straw by carbonization and followed by activation using potassium hydroxide (KOH). Activated carbon samples were prepared under different activation temperatures, i.e., 650,750 and $850^{\circ} \mathrm{C}$, and their physical and chemical properties were characterized accordingly. The BET surface area of the activated carbon samples was increased from 520 to $1048 \mathrm{~m}^{2} / \mathrm{g}$ with the increase of activation temperature from 650 to $850^{\circ} \mathrm{C}$. These values were much higher than the non-activated rice straw carbon i.e., $1.16 \mathrm{~m}^{2} / \mathrm{g}$. The pore sizes of the rice straw activated carbon were found to be mainly in mesopore size range of 2-50 $\mathrm{nm}$. Total carbon content of the AC sample was increased from $8.35 \%$ to $31.73 \%$ with the increase of activation temperature from 650 to $850^{\circ} \mathrm{C} . X R D$ and Raman spectroscopy confirmed the graphite properties of the activated carbons produced. SEM images proved high porosity of the $A C$ after $\mathrm{KOH}$ activation.
\end{abstract}

Keywords: Activated carbon; biomass; lignocellulosic

\section{ABSTRAK}

Dalam kajian ini, karbon teraktif berliang tinggi telah dihasilkan daripada jerami padi melalui proses pengkarbonan dan diikuti dengan pengaktifan bersama kalium hidroksida (KOH). Sampel karbon teraktif disediakan pada suhu pengaktifan yang berbeza, iaitu 650, 750 dan $850^{\circ} \mathrm{C}$ dan sifat fizikal dan kimia sampel tersebut dicirikan. Luas permukaan sampel arang teraktif meningkat daripada $520 \mathrm{ke} 1048 \mathrm{~m}^{2} / \mathrm{g}$ dengan peningkatan suhu pengaktifan daripada $650 \mathrm{ke} 850^{\circ} \mathrm{C}$. Nilai ini adalah jauh lebih tinggi berbanding sampel karbon jerami padi tanpa melalui proses pengaktifan, iaitu 1.16 $\mathrm{m}^{2} / \mathrm{g}$. Saiz liang karbon teraktif adalah pada saiz liang meso, iaitu dalam julat saiz 2-50 nm. Kandungan karbon bagi sampel arang teraktif telah meningkat daripada $8.35 \%$ kepada $31.73 \%$ dengan peningkatan suhu pengaktifan daripada 650 kepada $850^{\circ} \mathrm{C}$. Analisis XRD dan spektroskopi Raman telah membuktikan sifat grafit karbon teraktifyang terhasil. Imej SEM membuktikan sifat keliangan yang tinggi bagi karbon teraktifjerami padi selepas proses pengaktifan KOH.

Kata kunci: Biojisim; karbon teraktif; lignoselulosa

\section{INTRODUCTION}

Biochar or charcoal are carbon-based materials produced by carbonization using heating process to increase carbon content of the starting material (Sumrit et al. 2015). Charcoal can be produced from agriculture wastes such as paddy straw (Gao et al. 2011), husk (Muniandy et al. 2014), coconut waste (MohdIqbaldin et al. 2013), peanut shell (Wu et al. 2013), palm kernel shell (Rugayah et al. 2014), walnut shell (Yu et al. 2014), corn cob (Song et al. 2013) and sugarcane (Srenscek-Nazzal et al. 2013). Charcoal was the starting material to produce activated carbon (AC) which exhibits excellent absorption performance due to its high surface area, porosity and rich in active functional groups (Shamsuddin et al. 2016).

$\mathrm{AC}$ is rich in carbon, high surface area and consists of various pore sizes, including macro-, meso- and microsizes (Bhatnagar et al. 2013). It has a basic structural unit which is closely approximated by the structure of graphite. AC can be produced through activation process on carbonaceous materials like coal or cellulosic sources (Oh \& Park 2002). Most of AC materials are produced from coal, pitch, petroleum and high carbon content materials via physical or chemical activations (Chen et al. 2008). Due to high cost of coal, wide attention has been given to low cost agriculture wastes. Rice straw consists of hemicellulose $(35.7 \%)$, cellulose $(32 \%)$, lignin $(22.3 \%)$ and extractive (10\%) (Lim et al. 2012). AC can be derived from cellulose, hemicellulose, lignin and other components in lignocellulose materials (Danish et al. 2018).

AC can usually be prepared by physical or chemical activation. Physical activation process can be achieved by heating charcoal or carbonized materials in the presence of steam or carbon dioxide, while chemical activation involves the impregnation of charcoal with chemicals, such as potassium hydroxide (KOH) (Chen et al. 2009, 2008; Fierro et al. 2009; Oh \& Park 2002; Oh et al. 2003; 
Sobhy et al. 2015), sodium hydroxide $(\mathrm{NaOH})$ (Schroder et al. 2007), zinc chloride $\left(\mathrm{ZnCl}_{2}\right)$, iron oxide (Zainol et al. $2017)$ or phosphoric acid $\left(\mathrm{H}_{3} \mathrm{PO}_{4}\right)$, prior to heating in inert gas at high temperature (Kalderis et al. 2008). AC obtained from chemical activation possesses larger surface area and better mesoporosity (Viboon et al. 2008).

$\mathrm{AC}$ was preciously prepared from rice straw via two-steps method, i.e., carbonization and followed by activation. Two steps activation allows more activating agent to react with the carbon compounds and produce $\mathrm{AC}$ with higher pore volume and surface area (Basta et al. 2009). Alkali hydroxides, such as $\mathrm{NaOH}$ and $\mathrm{KOH}$, are generally used as activating agent to produce AC (Foo \& Hameed 2011; Guo et al. 2003; Perrin et al. 2004). It was reported that activation using $\mathrm{KOH}$ can produce $\mathrm{AC}$ with higher surface area and porosity compared to $\mathrm{NaOH}$ (Evans et al. 1999; Oh \& Park 2002).

In Malaysia, more than 3 million tonnes of rice straw was produced from approximately 680,000 acres of paddy field every year (Rosmiza et al. 2014). Unfortunately, big portion of the rice straw was left in the field or burned which creating air pollution. Therefore, it will be useful to utilize the paddy straw waste to produce valuable products. Since research works on the preparation of activated carbon from Malaysia's rice straw are still not widely reported, therefore, in this research, rice straw AC was prepared using two-steps method, i.e., carbonization and activation processes. The effect of activation temperature $\left(650^{\circ} \mathrm{C}, 750^{\circ} \mathrm{C}\right.$ and $\left.850^{\circ} \mathrm{C}\right)$ was also studied. The physical and chemical properties of the charcoal and AC were characterized by elemental analyses, Fourier-transform infrared (FTIR), Raman spectroscopy, Brunauer-EmmettTeller (BET), X-ray diffraction (XRD) and scanning electron microscopy (SEM).

Besides that, we also include the elemental analyses of raw rice straw and the produced activated carbon, which are of important to further understand the physical and chemical properties of the activated carbon produced.

\section{MATERIALS AND METHODS}

\section{MATERIALS}

Rice straw was obtained from a paddy field in Sekinchan, Selangor. The rice straw was washed with water and followed by drying in an oven at $105^{\circ} \mathrm{C}$ for $16 \mathrm{~h}$. The dried rice straw was cut into size range of $1-3 \mathrm{~cm}$ using a cutting machine. Potassium hydroxide $(\mathrm{KOH})$ in pellet form was purchased from Merck.

\section{METHODS}

Chemical activation The rice straw was undergone carbonization process in a closed chamber at $400^{\circ} \mathrm{C}$ for $4 \mathrm{~h}$ to produce rice straw charcoal (RSC). The produced charcoal was ground and sieved to size of 60 mesh. The charcoal was impregnated with $\mathrm{KOH}$ by soaking in $\mathrm{KOH}$ solution $(13 \mathrm{M})$ with a weight ratio of 1:4 (1 g RSC: $4 \mathrm{~mL}$ $\mathrm{KOH})$ for $24 \mathrm{~h}$. Then, the impregnated charcoal was filtered and oven dried at $105^{\circ} \mathrm{C}$ overnight. Activation process was done in a tube furnace under nitrogen gas flow $(100 \mathrm{~mL} /$ $\min )$ at various temperatures $\left(650,750\right.$ and $\left.850^{\circ} \mathrm{C}\right)$ for 2 h. After the activation process, the sample was cooled to room temperature and washed with $\mathrm{HCl}$ solution $(1.0 \mathrm{M})$ and washed several times with deionized water until $\mathrm{pH} 6$ to 7 of the rinse was achieved. The samples were labeled as RS (rice straw), RSC (rice straw charcoal). RSAC650, RSAC750 and RSAC 850 are referred to the rice straw AC activated at $650^{\circ} \mathrm{C}, 750^{\circ} \mathrm{C}$, and $850^{\circ} \mathrm{C}$, respectively.

\section{CHARACTERIZATIONS}

All samples were analyzed to determine the percentage carbon, hydrogen and nitrogen elements. $30 \mathrm{mg}$ of the samples was mixed with $60 \mathrm{mg}$ titanium and wrapped with aluminum foil prior to the analyses using an Elemental analyzer (Elementar Macro cube). Chemical functional groups of the sample surface were analyzed using a FTIR Spectrometer (Bruker, Alpha). Total surface area and porosity of the RSAC and RSC samples were evaluated using $\mathrm{N}_{2}$ adsorption-desorption analysis (Micromeritics ASAP 2010) according to the standard nitrogen adsorption and desorption at $77 \mathrm{~K}$. The samples were degassed prior to be analyzed under vacuum at $110^{\circ} \mathrm{C}$ for $10 \mathrm{~h}$.

$\mathrm{X}$-ray diffraction (XRD) was conducted to determine the crystallinity of the samples using a powder X-ray diffraction (Bruker AXS model D8 advance), which was equipped with $\mathrm{Cu}-\mathrm{K} \alpha$ radiation $(\lambda=0.15406 \AA)$ and voltage supplied at $40 \mathrm{kV}$ and current of $40 \mathrm{~mA}$. The step size was set at $0.025^{\circ}$ from $10^{\circ}$ to $90^{\circ}$. Raman spectrum of the samples was obtained using a micro-Raman system equipped with a $532 \mathrm{~nm}$ laser (Technospex Ltd, Singapore). Scanning electron microscopy (SEM) of FEI model Quanta 400 was used to observe surface morphology of the RSAC and RSC samples.

\section{RESULTS AND DISCUSSION}

The elemental compositions of the RS, RSC and RSAC are demonstrated in Table 1. All AC samples treated with $\mathrm{KOH}$ contained higher carbon and lower hydrogen, sulfur and nitrogen contents as compared to RS and RSC. $\mathrm{KOH}$ activation has promoted deeper carbonization and enhanced the chemical changes in the material which increased the carbon content and decreased the hydrogen, nitrogen and sulfur contents (Yakout \& El-Deen 2016). AC was highly formed after the reaction of the KOH's oxygen which assists the removal of cross-linking and stabilizes the carbon atoms in crystalline (Viboon et al. 2008). The removal of hydrocarbon during activation with $\mathrm{KOH}$ has improved carbon content and has reduced the hydrogen content (Mohd Iqbaldin et al. 2013; Zhang et al. 2008).

Figure 1 demonstrates the FTIR spectra of the RS, RSC and RSAC samples. The spectra of RSC and RSAC at $3100-3600 \mathrm{~cm}^{-1}$ for $\mathrm{OH}$ stretching absorption decreased as compared to RS due to the absence of $\mathrm{OH}$ from the results of heating during the carbonization and activation 
TABLE 1. Elemental compositions of rice straw activated carbon

\begin{tabular}{lcccc}
\hline Item & $\mathrm{C}(\%)$ & $\mathrm{H}(\%)$ & $\mathrm{N}(\%)$ & $\mathrm{S}(\%)$ \\
\hline RS & 37.93 & 6.19 & 0.99 & 2.07 \\
RSC & 61.08 & 3.24 & 0.93 & 1.38 \\
RSAC650 & 66.18 & 1.99 & 0.79 & 0.15 \\
RSAC750 & 70.92 & 2.91 & 0.73 & 0.14 \\
RSAC850 & 80.46 & 1.99 & 0.72 & 0.13 \\
\hline
\end{tabular}

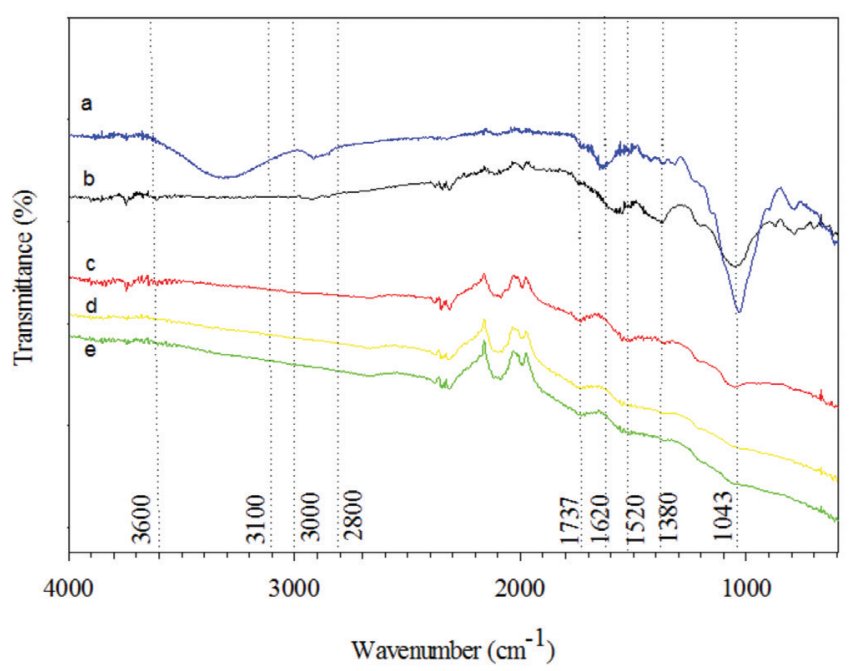

FIGURE 1. FTIR spectra of (a) RS, (b) RSC, (c) RSAC650, (d) RSAC850, and (e) RSAC750

processes. It may be due to the development of the aromatic structure (Oh et al. 2003). The absorbance at $1043 \mathrm{~cm}^{-1}$ was O-H bending (San Miguel et al. 2003). RS and RSC prepared exhibited weak bands at 2800-2900 $\mathrm{cm}^{-1}$ indicating stretching vibrations of the $\mathrm{C}-\mathrm{H}$ bonds of the methylene groups $\left(-\mathrm{CH}_{2}-\right)($ Cazetta et al. 2011). These bands were, however, not presence in the RSAC samples that were activated at 650,750 , and $850^{\circ} \mathrm{C}$. This might be due to the decomposition of the $\mathrm{C}-\mathrm{H}$ bonds to develop an aromatic $\mathrm{C}=\mathrm{C}$ bond which is more stable at higher activation temperature (Zhu et al. 2012). The results were related with the decrease of the $\mathrm{H}$ contents of the RSC and RSAC as discussed early. The peak at $1380 \mathrm{~cm}^{-1}$ is attributed to the aliphatic deformation of $\mathrm{CH}_{2}$ or $\mathrm{CH}_{3}$ groups or $\mathrm{O}-\mathrm{H}$ bending of phenolic- $\mathrm{OH}$. It became weaker for the $\mathrm{AC}$ samples, suggesting the dehydration and aromatization occurred as a result of the decomposition and condensation of volatile matters (Wu et al. 2012). The band at $1737 \mathrm{~cm}^{-1}$, which belongs to $\mathrm{C}=\mathrm{O}$ stretching in aldehyde appeared on the surface site of RSAC, was due to instability of thermal of aldehyde and ketone group in the high temperature (Hamza et al. 2015). The peak around 1520-1620 $\mathrm{cm}^{-1}$ is corresponding to the $\mathrm{C}=\mathrm{C}$ stretching in aromatic rings (El-Hendawy 2003).

The surface area $\left(\mathrm{S}_{\mathrm{BET}}\right)$, total pore volume $\left(\mathrm{V}_{\text {total }}\right)$ and pore sizes of RSAC and RSC obtained from $\mathrm{N}_{2}$ absorption are listed in Table 2. We also included results from previous studies for comparison purposes. RSAC exhibited higher BET surface area ranging from 520 to $1048 \mathrm{~m}^{2} / \mathrm{g}$, meanwhile the RSC sample was only $1.16 \mathrm{~m}^{2} / \mathrm{g}$. BET surface area increased with increasing activation temperature. Activation at $850^{\circ} \mathrm{C}$ produced $\mathrm{AC}$ with the highest surface area $\left(1048 \mathrm{~m}^{2} / \mathrm{g}\right)$ followed by $750^{\circ} \mathrm{C}\left(928 \mathrm{~m}^{2} / \mathrm{g}\right)$ and $650^{\circ} \mathrm{C}\left(520 \mathrm{~m}^{2} / \mathrm{g}\right)$. The role of temperature is to assist the development pores on the surface by heat induced internal volumetric widening of pores (Foo \& Hammed 2012). Improvement of BET surface area could also due to the release of volatile components during the heat activation process. It was probable that $\mathrm{KOH}$ was reduced (Equations 1, 2 and 3) into metallic potassium (K) during the activation process. Metal of $\mathrm{K}$ was diffused into the layer of carbon whenever activation temperature reaches the boiling point of $\mathrm{K}\left(760^{\circ} \mathrm{C}\right)$ and created pores in the carbon structure which increased the porosity and surface area (Rostamiam et al. 2015). Besides, higher activation temperature could release more volatile components from the material hence increased the BET surface area. $\mathrm{KOH}$ as activating agent was reacted with the reactive center of the carbonized material, such as disorganized carbon, carbon with heteroatoms and carbon on graphene edges thus created new pores and widening the existence ones (Zhang et al. 2008). RSAC produced from the $\mathrm{KOH}$ activation has surface area more than $500 \mathrm{~m}^{2} / \mathrm{g}$, suggesting that it can be considered as functional or practical AC. Total pore volume of RSAC increased from 0.32 to $0.64 \mathrm{~cm}^{3} / \mathrm{g}$ with the increase of activation temperature from $650^{\circ} \mathrm{C}$ to $850^{\circ} \mathrm{C}$. Total pore volume of the RSC sample is $0.0028 \mathrm{~cm}^{3} / \mathrm{g}$. Increase in the surface area was attributed by the increase 
of mesopore volume (Viboon et al. 2008). The possible chemical reactions between $\mathrm{KOH}$ and carbon occurred during the activation process as follows (Chunlan et al. 2005):

$$
\begin{aligned}
& 4 \mathrm{KOH}+\mathrm{C} \rightarrow \mathrm{K}_{2} \mathrm{CO}_{3}+\mathrm{K}_{2} \mathrm{O}+2 \mathrm{H}_{2} \\
& 2 \mathrm{~K}_{2} \mathrm{O}+\mathrm{C} \rightarrow 4 \mathrm{~K}+\mathrm{CO}_{2} \\
& \mathrm{~K}_{2} \mathrm{CO}_{3}+2 \mathrm{C} \rightarrow 2 \mathrm{~K}+3 \mathrm{CO}
\end{aligned}
$$

It can be seen that the surface area of activated carbon produced from this study is lower compared to the works done by Basta et al. (2009), Oh and Park (2002) and Zhang et al. (2009). Basta et al. (2009) and Oh and Park (2002) applied higher temperature during the carbonization process, i.e. $700-800^{\circ} \mathrm{C}$, which is much higher than $400^{\circ} \mathrm{C}$ in our study. While Zhang et al. (2000) used much higher concentration of $\mathrm{KOH}$ for the activation process of the rice straw carbon. The purpose of selecting low carbonization temperature and $\mathrm{KOH}$ concentration is to minimize the cost and chemical usage for the production of activated carbon from rice straw.

Average pore size of RSAC varies from $2.45 \mathrm{~nm}$ to 2.49 $\mathrm{nm}$ and $9.72 \mathrm{~nm}$ for RSC as tabulated in Table 2. Figure 2 shows the size distribution of the RSAC. The results demonstrated that majority of the pores within the size of 2-50 nm fall under mesopore size, i.e., 86.14, 88.43, and $88.79 \%$ for the RSAC650, RSAC750, and RSAC 850 , respectively. This values are much higher than that of the RSC sample before activation. According to Everett (1972), pore size can be classified into three types which are micropore (less than $2 \mathrm{~nm}$ ), mesopore (2-50 nm) and macropore (more than $50 \mathrm{~nm}$ ). Mesoporous material is usually suitable for adsorption of liquid pollutants due to larger sizes of liquid molecules (Sobhy et al. 2015). It was reported by Altenor et al. (2009), that the methylene blue molecule susceptible to lodge on the mesoporous adsorbent which has a pore diameter larger than $1.3 \mathrm{~nm}$.

Figure 3 depicts XRD diagrams of the RSC and RSAC $\left(850^{\circ} \mathrm{C}\right.$ activation temperature). RSAC showed two broad peaks at $20^{\circ}-30^{\circ}$ and $40^{\circ}-50^{\circ}$ which indicated the presence of amorphous carbon. The crystal structure has disappeared and micropores were formed during the activation process (Ma \& Ouyang 2013). The two broad peaks could be attributed to the reflection from the (002) and (100) planes (Tang et al. 2012). It was the characteristics of amorphous

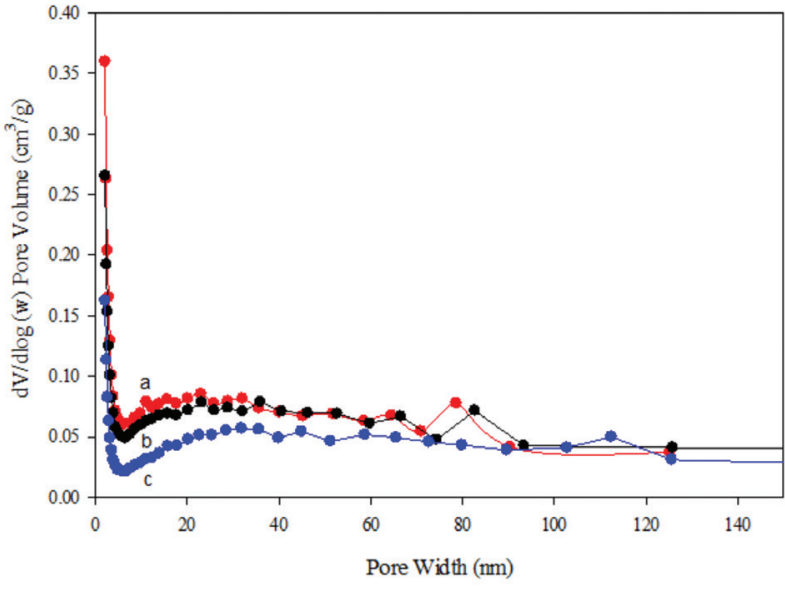

FIGURE 2. Pore distribution of (a) RSAC850, (b) RSAC750 and (c) RSAC650

carbon with carbon rings that disorderly stack up (Tang et al. 2012). Thus, the AC has some degree of micro-crystallinity with turbostratic graphite structure (Tang et al. 2012). Srenscek-Nazzal et al. (2013) also reported the same finding that the both broad peaks meant the AC sample made of graphite-like micro-crystallites bounded by a crosslinking network consisted of several graphite-like layer.

Raman spectra of the RSAC samples are presented in Figure 4. There are two broad peaks found at $1360 \mathrm{~cm}^{-1}$ (D band) and $1580 \mathrm{~cm}^{-1}$ (G band) in all spectra corresponding to the $\mathrm{C}-\mathrm{C}$ bond vibrations of carbon atom with $\mathrm{sp}^{2}$ electronic configuration in graphene sheet structure for $\mathrm{G}$ band and the disordered and imperfect structures of carbon materials for D band, respectively (Kayiran et al. 2004; Pol et al. 2004; Zhang et al. 2008). The narrower $G$ band and broad D band proved that the RSAC had small graphene sheets with a low graphitization degree (Zhang et al. 2009). These means that the carbon atom of RSAC samples have assembled into graphene sheet structure as a results of carbonization and activation. The $\mathrm{G}$ band found weaker for the AC sample produced at higher activation temperature as shown in Figure 4. The same patterns were also reported by Srenscek-Nazzal et al. (2013).

SEM micrograph of the RSC of closed pores on the surfaces (Figure 5(a)). However, after the $\mathrm{KOH}$ activation at $850^{\circ} \mathrm{C}$, pores structure of the RSAC 850 was developed (as shown in Figure 5(b)). Chemical activation resulted

TABLE 2. Porosity properties of the RSC and RSAC

\begin{tabular}{lccccccc}
\hline Samples & RSC & RSAC650 & RSAC750 & RSAC850 & $\begin{array}{c}\text { Zhang } \\
\text { et al. 2009 }\end{array}$ & $\begin{array}{c}\text { Basta } \\
\text { et al. 2009 }\end{array}$ & $\begin{array}{c}\text { Oh \& Park } \\
2002\end{array}$ \\
\hline $\mathrm{S}_{\mathrm{BET}}\left(\mathrm{m}^{2} \mathrm{~g}^{-1}\right)$ & 1.16 & 520.29 & 928.07 & 1048.30 & 2950 & 1393 & 2200 \\
$\mathrm{~V}_{\text {total }}\left(\mathrm{cm}^{3} / \mathrm{g}\right)$ & 0.0028 & 0.32 & 0.57 & 0.64 & 1.62 & - & 1.15 \\
$\mathrm{~V}_{\text {micro }}\left(\mathrm{cm}^{3} / \mathrm{g}\right)$ & - & 0.0170 & 0.0348 & 0.0436 & - & - & 0.54 \\
$\mathrm{~V}_{\text {meso }}\left(\mathrm{cm}^{3} / \mathrm{g}\right)$ & 0.00127 & 0.276 & 0.504 & 0.568 & - & - & 0.54 \\
Average pore size $(\mathrm{nm})$ & 9.72 & 2.49 & 2.47 & 2.45 & - & - & - \\
\hline
\end{tabular}




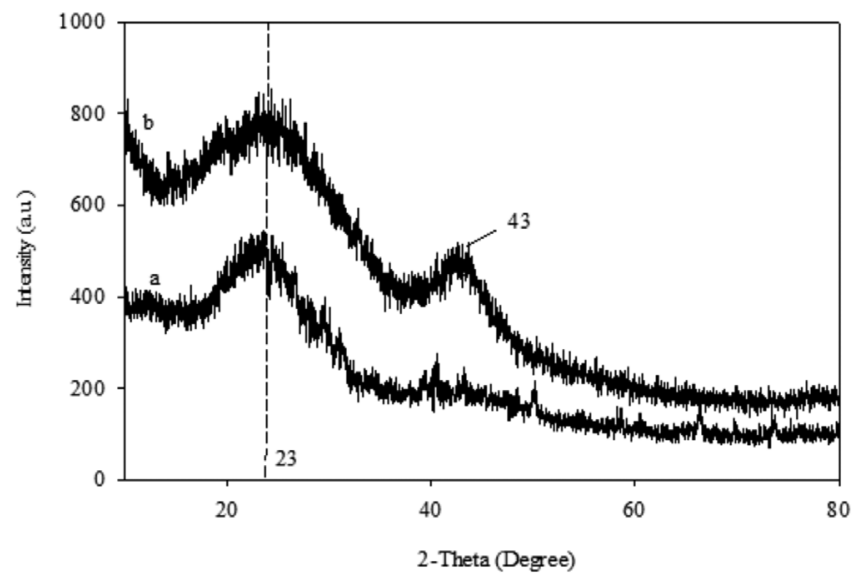

FIGURE 3. XRD diagrams of (a) RSC and (b) RSC850

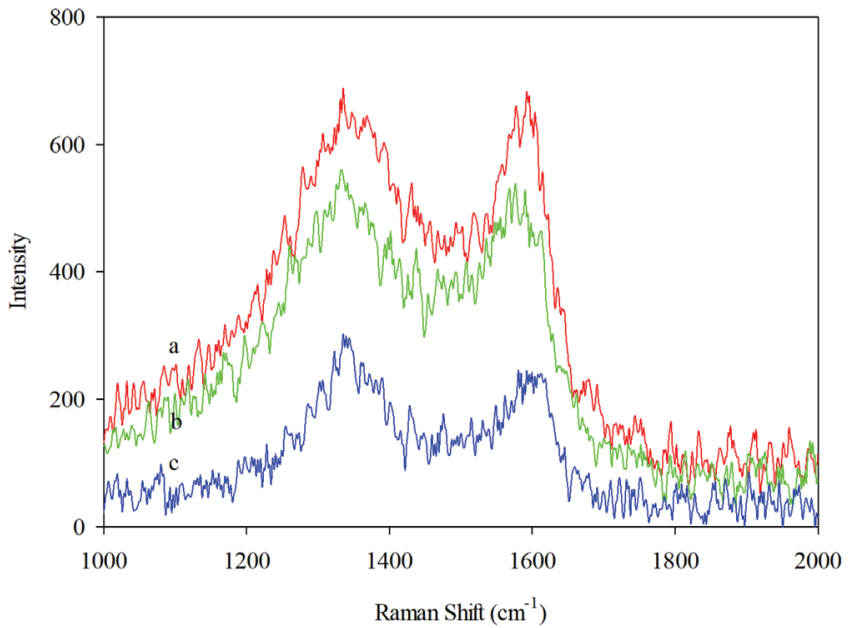

FIGURE 4. Raman spectra of (a) RSAC650, (b) RSAC750 and (c) RSAC850
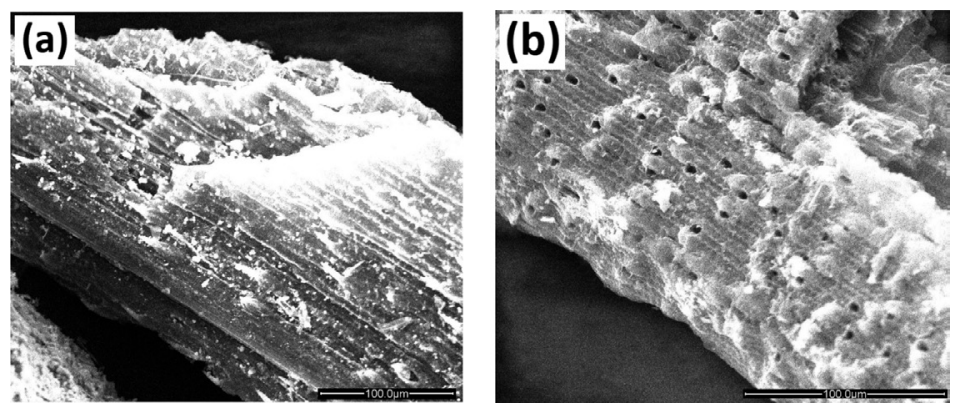

FIGURE 5. SEM images of (a) RSC and (b) RSAC850

in carbon porous structure which opened the pores on the surface of the RSAC. The high pores were resulted in the high BET surface area of RSAC as discussed previously. These results were consistent with results obtained from previous study (Oh \& Park 2002; Oh et al. 2003).

\section{CONCLUSION}

$\mathrm{AC}$ was produced from rice straw in a laboratory-scale by carbonization and subsequent $\mathrm{KOH}$ activation. Carbon content of the RSAC was varied from $66.18 \%$ to $80.46 \%$, depending on the activation temperature. BET surface area of the RSAC prepared at $850^{\circ} \mathrm{C}$ attained a maximum of $1048 \mathrm{~m}^{2} / \mathrm{g}$. Pore sizes of the RSAC were found to be mainly in mesopore sizes. FTIR analyses on the surface of RSAC demonstrated different of functional groups than the RSC. The physical characteristics of RSAC were proved from the XRD and Raman spectroscopy analyses where it made of graphite-like micro-crystallites and in graphene sheet structure or disordered of carbon materials, respectively. 
SEM proved the porous structure of the RSAC produced by $\mathrm{KOH}$ activation.

\section{ACKNOWLEDGEMENTS}

We would like to thank the Malaysian Agricultural Research and Development Institute (MARDI) and the Ministry of Higher Education, Malaysia (FRGS/1/2016/ STG01/UKM/02/3) for the financial support provided. We would also like to thanks Puan Norzaimawati Aman Nejis for the SEM analyses.

\section{REFERENCES}

Altenor, S., Carene, B., Emmanuel, E., Lambert, J., Ehrhardt, J.J. \& Gaspard, S. 2009. Adsorption studies of methylene blue and phenol onto vetiver roots activated carbon prepared by chemical activation. Journal of Hazardous Materials 165: 1029-1039.

Basta, A.H., Fierro, V., El-Saied, H. \& Celzard, A. 2009. 2-steps $\mathrm{KOH}$ activation of rice straw: An efficient method for preparing high-performance activated carbons. Bioresource Technology 100: 3941-3947.

Bhatnagar, A., Hogland, W., Marques, M. \& Sillanpää, M. 2013. An overview of the modification methods of activated carbon for its water treatment applications. Chemical Engineering Journal 219: 499-511.

Cazetta, A.L., Vargas, A.M.M., Nogami, E.M., Kunita, M.H., Guilherme, M.R., Martins, A.C., Silva, T.L., Moraes, C.G. \& Almeida, V.C. 2011. NaOH-activated carbon of high surface area produced from coconut shell: Kinetics and equilibrium studies from the methylene blue adsorption. Chemical Engineering Journal 174: 117-125.

Chen, J.S., Zhang, F. \& Li, G.D. 2008. Effects of raw material texture and activation manner on surface area of porous carbons derived from biomass resources. Journal of Colloid and Interface Science 327: 108-114.

Chunlan, L., Shaoping, X., Yixiong, G., Shuqin, L. \& Changhou, L. 2005. Effect of pre-carbonization of petroleum cokes on chemical activation process with $\mathrm{KOH}$. Carbon 43: 22952301.

Danish, M. \& Ahmad, T. 2018. A review on utilization of wood biomass as a sustainable precursor for activated carbon production and application. Renewable and Sustainable Energy Reviews 87: 1-21.

El-Hendawy, A.N.A. 2003. Influence of $\mathrm{HNO}_{3}$ oxidation on the structure and absorptive properties of the corncob based activated carbon. Carbon 41: 713-722.

Evans, M.J.B., Halliop, E. \& Macdonald, J.A.F. 1999. The production of chemically activated carbon. Carbon 37: 269-274.

Everett, D.H. 1972. Manual of symbols and terminology for physicochemical quantities and units, Appendix II: definitions, terminology and symbols in colloid and surface chemistry. Pure Appl. Chem. 31(4): 577-638.

Foo, K.Y. \& Hameed, B.H. 2011. Utilization of rice husks as a feedstock for preparation of activated carbon by microwave induced $\mathrm{KOH}$ and $\mathrm{K} 2 \mathrm{CO} 3$ activation. Bioresource Technology 102: 9814-9817.

Gao, P., Liu, Z.H., Xue, G., Han, B. \& Zhou, M.H. 2011. Preparation and characterization of activated carbon produced from rice straw by (NH4)2HPO4 activation. Bioresource Technology 102: 3645-3648.
Guo, Y.P., Yang, S.F., Fu, W.Y., Qi, J.R., Li, R.Z., Wang, Z.C. \& $\mathrm{Xu}, \mathrm{H} . \mathrm{D} .2003$. Adsorption of malachite green on micro- and mesoporous rice husk-based active carbon. Dyes Pigments 56: 219-229.

Hamza, U.D., Nasri, N.S., Amin, N.S., Mohammed, J. \& Zain, H.M. 2015. Characteristics of oil palm shell biochar and activated carbon prepared at different carbonization time. Desalin Water Treatment 57(17): 7999-8006.

Kalderis, D., Koutoulakis, D., Paraskeva, P., Diamadopoulos, E., Otal, E., del Valle, J.O. \& Fernandez-Pereira, C. 2008. Adsorption of polluting substances on activated carbons prepared from rice husk and sugarcane bagasse. Chemical Engineering Journal 144: 42-50.

Kayiran, S.B., Lamari, F.D. \& Levesque, D. 2004. Adsorption properties and structural characterization of activated carbons and nanocarbons. Journal Physic Chemistry B 108(39): 15211-15215.

Lembaga Kemajuan Pertanian Muda (MADA). 2010. Laporan Tahunan. Alor Setar, Kedah.

Lim, J.S., Manan, Z.A., Alwi, S.R.W. \& Hashim, H. 2012. A review on utilization of biomass from rice industry as a source of renewable energy. Renewable and Sustainable Energy Reviews 16(5): 3084-3094.

Ma, X. \& Ouyang, F. 2013.Adsorption properties of biomassbased activated carbon prepared with spent coffee grounds and pomelo skin by phosphoric acid activation. Applied Surface Science 268: 566-570.

MohdIqbaldin, M.N., Khudzir, I., MohdAzlan, M.I., Zaidi, A.G., Surani, B. \& Zubri, Z. 2013. Properties of coconut shell activated carbon. Journal of Tropical Forest Science 25(4): 497-503.

Muniandy, L., Adam, F., Mohamed, A.R. \& Ng, E.P. 2014. The synthesis and characterization of high purity mixed microporous/mesoporous activated carbon from rice husk using chemical activation with $\mathrm{NaOH}$ and $\mathrm{KOH}$. Microporous Mesoporous Material 197: 316-323.

Oh, G.H. \& Park, C.R. 2002. Preparation and characteristics of rice straw based porous carbon with high adsorption capacity. Fuel 81: 327-336.

Oh, G.H., Yun, C.H. \& Park, C.R. 2003. Role of KOH in the one-stage $\mathrm{KOH}$ activation of cellulosic biomass. Carbon Science 4: 180-184.

Perrin, A., Celzard, A., Albiniak, A., Kaczmarczyk, J., Mareche, J.F. \& Furdin, G. 2004. NaOH activation of anthracites: Effect of temperature on pore textures and methane storage ability. Carbon 42: 2855-2901.

Pol, V.G., Motiei, M., Gedanken, A., Calderon-Moreno, J. \& Yoshimura, M. 2004. Carbon spherules: Synthesis, properties and mechanistic elucidation. Carbon 42: 111-116.

Rosmiza, M.Z., Davies, W.P., Rosniza Aznie, C.R., Mazdi, M. \& Jabil, M.J. 2014. Farmers' knowledge on potential uses of rice straw: An assessment in MADA and Sekinchan, Malaysia. Malaysian Journal of Society and Space 5: 30-43.

Rostamian, R., Heidarpour, M., Mousavi, S.F. \& Afyuni, M. 2015. Characterization and sodium sorption capacity of biochar and activated carbon prepared from rice husk. Journal Agricultural Science Technology 17: 1057-1069.

Rugayah, A.F., Astimar, A.A. \& Norzita, N. 2014. Preparation and characterization of activated carbon from palm kernel shell by physical activation with steam. Journal Oil Palm Research 26: 251-264.

San Miguel, G., Fowler, G.D. \& Sollars, C.J. 2003. A study of the characteristics of activated carbons produced by steam 
and carbon dioxide activation of waste tyre rubber. Carbon 41: 1009-1016.

Schroder, E., Thomauske, K., Weber, C., Hornung, A. \& Tumiatti, V. 2007. Experiments on the generation of activated carbon from biomass. Journal of Analytical and Applied Pyrolysis 79: 106-111.

Shamsuddin, M.S., Yusoff, N.R.N. \& Sulaiman, M.A. 2016. Synthesis and characterization of activated carbon produced from kenaf core fiber using $\mathrm{H}_{3} \mathrm{PO}_{4}$ activation. Procedia Chemistry 19: 558-565.

Sobhy, M.Y., Hakim, A.E., Daifullah, M. \& Sohair, A.E. 2015. Pore structure characterization of chemically modified biochar derived from rice straw. Environmental Engineering and Management Journal 14(2): 473-480.

Song, M., Jin, B., Xiao, R., Yang, L., Wu, Y., Zhong, Z. \& Huang, Y. 2013. The comparison of two activation techniques to prepare activated carbon from corn cob. Biomass Bioenergy 48: $250-256$

Srenscek-Nazzal, J., Kaminskaa, W., Michalkiewicza, B. \& Korenb, Z. 2013. Production, characterization and methane storage potential of $\mathrm{KOH}$-activated carbon from sugarcane molasses. Industrial Crops and Products 47: 153-159.

Sumrit, M., Supattra, I. \& Laddawan, A. 2015. Effect of temperature on micropore of activated carbon from sticky rice straw by $\mathrm{H}_{3} \mathrm{PO}_{4}$ activation. Carbon: Science and Technology 7: 24-29.

Tang, Y.B., Liu, Q. \& Chen, F.Y. 2012. Preparation and characterization of activated carbon from waste Ramulus mori. Chemical Engineering Journal 203: 19-24.

Viboon, S., Chiravoot, P., Duangdao A. \& Duangduen, A. 2008. Preparation and characterization of activated carbon from the pyrolysis of physic nut (Jatropha curcas L.) waste. Energy \& Fuels 22: 31-37.

Wu, M., Guo, Q. \& Fu, G. 2013. Preparation and characteristics of medicinal activated carbon powders by $\mathrm{CO}_{2}$ activation of peanut shells. Powder Technology 247: 188-196.

Wu, W., Yang, M., Feng, Q., McGrouther, K., Wang, H., Lu, H.H. \& Chen, Y.X. 2012. Chemical characterizations of rice straw-derived bio char for soil amendment. Biomass \& Bioenergy 47: 268-276.

Yakout, S.M. \& El-Deen, G.S 2016. Characterization of activated carbon prepared by phosphoric acid activation of olive stones. Arabian Journal of Chemistry 9: S1155-S1162.

Yu, Q., Li, M., Ning, P., Yi, H. \& Tang, X. 2014. Preparation and phosphine adsorption of activated carbon prepared from walnut shells by $\mathrm{KOH}$ chemical activation. Separation Science Technology 49: 2366-2375.

Zainol, M.M., Amin, N.A.S. \& Asmadi, M. 2017. Preparation and characterization of impregnated magnetic particles on oil palm frond activated carbon for metal ions removal. Sains Malaysiana 46(5): 773-782.

Zhang, F., Wang, K.X., Li, G.D. \& Chen, J.S. 2009. Hierarchical porous carbon derived from rice straw for lithium ion batteries with high-rate performance. Electrochemistry Communication 11: 130-133.
Zhang, F., Ma, H., Chen, J., Li, G.D., Zhang, Y. \& Chen, J.S. 2008. Preparation and gas storage of high surface area microporous carbon derived from biomass source cornstalks. Bioresource Technology 99: 4803-4808.

Zhu, K., Fu, H., Zhang, J., Ly, X., Tang, J. \& Xu, X. 2012. Studies on removal of $\mathrm{NH}_{4}^{+}$-N from aqueous solution by using the activated carbons derived from rice husk. Biomass \& Bioenergy 43: 18-25.

Mohamad Jani Saad, Chin Hua Chia \& Sarani Zakaria Bioresources and Biorefinery Laboratory

Materials Science Program

Faculty of Science and Technology

Universiti Kebangsaan Malaysia

43600 UKM Bangi, Selangor Darul Ehsan

Malaysia

Mohd Shaiful Sajab

Research Centre for Sustainable Process Technology

Faculty of Engineering and Built Environment

Universiti Kebangsaan Malaysia

43600 UKM Bangi, Selangor Darul Ehsan

Malaysia

Sufian Misran

Forest Research Institute of Malaysia

52100 Kepong, Selangor Darul Ehsan

Malaysia

Mohamad Jani Saad \& Mohammad Hariz Abdul Rahman

Green Technology Program

Agrobiodiversity and Environment Research Centre

Malaysian Agriculture Research and Development Institute

43400 Serdang, Selangor Darul Ehsan

Malaysia

Siew Xian Chin

ASASIpintar Program

Pusat PERMATApintar $^{\mathbb{B}}$

Universiti Kebangsaan Malaysia

43600 UKM Bangi, Selangor Darul Ehsan

Malaysia

*Corresponding author; email: chia@ukm.edu.my

Received: 1 June 2018

Accepted: 12 October 2018 